\title{
CTGF-proteinet beskytter mot hjertesvikt
}

\author{
Proteinet bindevevsvekstfaktor (CTGF) kan begrense skadene på hjertet \\ etter hjerteinfarkt og beskytte mot hjertesviktutvikling, viser funn fra \\ Jørgen A. Gravnings doktorgradsarbeid.
}

- Hjertesvikt fortsatt er en viktig årsak til sykelighet og dødelighet på verdensbasis, til tross for store fremskritt i behandlingen. Det har lenge vært kjent at proteinet bindevevsvekstfaktor (Connective Tissue Growth Factor, CTGF) er indusert i myokard ved hjertesvikt og etter hjerteinfarkt. Hvilken funksjon dette proteinet har ved hjertesvikt, har derimot ikke vært kartlagt, sier Jørgen A. Gravning.

- Vi har sett på effektene av CTGF i mus som genetisk overuttrykker CTGF i hjertet, og vi har tilført rekombinant protein direkte til kardiomyocytter (hjertemuskelceller). Vi har også studert serumnivåene av CTGF hos pasienter som har gjennomgått hjerteinfarkt. Vi fant at CTGF beskytter mot utvikling av hjertesvikt etter hjerteinfarkt i mus. Beskyttelsen skyldes at CTGF øker hjertemuskelcellenes hypoksitoleranse ved å aktivere beskyttende signalveier og gener i hjertemuskelcellene. Arrvevet etter hjerteinfarktet blir dermed mindre. CTGF kan også være en bidragsyter til at stamceller rekrutteres til arrvevet etter hjerteinfarkt slik at nye hjertemuskelceller dannes. I tillegg ser det ut til at CTGF begrenser skadelige effekter av høyt blodtrykk. Vi fant at stigende nivåer av CTGF i blodet hos pasienter etter hjerteinfarkt er assosiert med mindre arrdanning og bedret hjertefunksjon etter ett år, sier Gravning.

- Resultatene gir viktig ny kunnskap om sykdomsmekanismene ved hjerteinfarkt og hjertesvikt og vil i fremtiden kunne bidra til bedret pasientbehandling, mener Gravning.

\section{Hanne Støre Valeur}

hanne.store.valeur@legeforeningen.no

Tidsskriftet

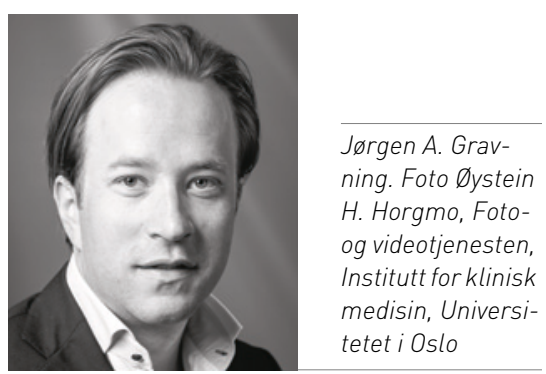

Disputas

Jørgen A. Gravning disputerte for ph.d.-graden ved Universitetet i Oslo 23.5. 2013. Tittelen på avhandlingen er Cardioprotective mechanisms in ischemia-reperfusion injury and heart failure experimental and clinical studies dissecting the functional effects of connective tissue growth factor (CTGF/CCN2) in the heart.

\section{Arbeidsdeltakelse hos personer med psykoselidelse}

\author{
Arbeidsdeltakelsen blant personer med psykoselidelse er generelt lav. \\ Marte Tandberg har sett på hvor mange personer med psykoselidelse \\ som jobber og hva som gjør at disse menneskene står i arbeid.
}

varende oppmerksomhet har betydning for arbeidsstatus over tid for personer med førstegangspsykose. Dette kan tyde på at sammenhengen mellom kognisjon og arbeid ikke er like sterk som tidligere rapportert, i alle fall fra tverrsnittsstudier. Andre sykdomsrelaterte og ytre systemfaktorer, som f.eks. sjenerøse velferdsordninger, kan ha større betydning.

- Funnene peker på betydningen av å undersøke et bredere spekter av potensielle faktorer som kan påvirke arbeidsfunksjon. Dette kan gi viktig informasjon om hvor man skal sette inn tiltak for å øke arbeidsdeltakelsen for personer med psykoselidelse, mener Tandberg.

\section{Hanne Støre Valeur}

hanne.store.valeur@legeforeningen.no

Tidsskriftet

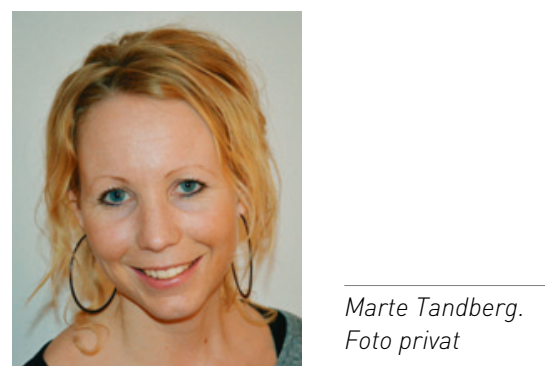

Disputas

Marte Tandberg disputerte for ph.d.-graden ved Universitetet i Oslo den 7.5. 2013. Tittelen på avhandlingen er The relationship between neurocognition, symptoms and employment status in patients with psychotic disorders. men en oppfølgingsstudie viste at god ved- 